\title{
Physicochemical and biological activity studies on complexes of some transition elements with mixed ligands of glycine and urea
}

\author{
Maher Ali Al-Maqtari ${ }^{1+}$, Mohammed Kassem Al-Qadasy ${ }^{1}$, Yasmin Mosa'd Jamil ${ }^{1}$, Fathi Mohammed Al-Azab ${ }^{1}$, Amani A. \\ Al-Gaadbi
}

${ }^{1}$ Sana'a University, Faculty of Science, Chemistry Department, Sana'a, Yemen

+ Corresponding author: Maher Ali Al-Maqtari, e-mail address: al.maqtarimaher@yahoo.com

$\begin{array}{ll}\text { ARTICLE INFO } & \text { Keywords: } \\ \text { Article history: } & \text { 1. urea } \\ \text { Received: August 8, } 2018 & \text { 2. glycine } \\ \text { Accepted: November 11, } 2018 & \text { 3. transition elements } \\ \text { Published: December 5, } 2018 & \text { 4. complexes }\end{array}$

ABSTRACT: The reaction of urea (ur) and glycine (gly) with the metal ions $\mathrm{Co}(\mathrm{II}), \mathrm{Ni}(\mathrm{II})$ and $\mathrm{Cu}(\mathrm{II})$ in ethanolic solution of $1 \mathrm{M}: 1 \mathrm{~L}_{1}: 1 \mathrm{~L}_{2}$ molar ratio (where $\mathrm{M}=\mathrm{Co}(\mathrm{II}), \mathrm{Ni}(\mathrm{II})$ and $\mathrm{Cu}(\mathrm{II})$, and $\mathrm{L}_{1}=$ urea $\mathrm{L}_{2}=$ glycine) led to the preparation of complexes of the general formula $\left[\mathrm{M}(\mathrm{ur})(\mathrm{gly})\left(\mathrm{H}_{2} \mathrm{O}\right)_{2}\right] \mathrm{Cl}$. Elemental microanalysis (CHN), molar conductivity measurements, IR, ${ }^{1} \mathrm{HNMR}$, Mass and UV-VIS spectroscopic, and magnetic susceptibility measurements were used for the characterization of the compounds. Thermal analyses were used for the complexes degradation characterization. The complexes have an octahedral geometry and are of electrolytic nature in DMSO solvent with the absence of inner-sphere coordination of the chloride anion. An inhibition zone was observed for Ni-urea-glycine complex against Escherichia coli when the biological activity was considered.

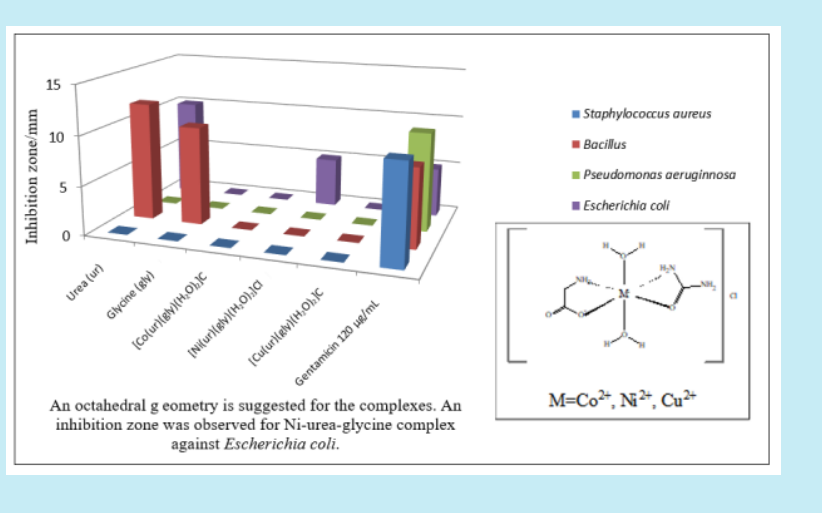

All life forms on earth consist of the simplest proteinaceous amino acid, called glycine or amino acetic $\operatorname{acid}^{7}$. Glycine is a neutral, aliphatic, optically inactive nonessential amino $\mathrm{acid}^{8}$ and it is the only protein amino acid that does not have optical isomers9. Most of the metal ions form mono, bis and tris complexes with glycine that acts as a bidentate ligand forming stable 5-membered chelating rings via the $\mathrm{N}$ atom of the amino group and $\mathrm{O}$ atom of carboxylate group ${ }^{10}$.

The mixed ligand complexes of urea and glycine acid with $\mathrm{Co}$ (II), $\mathrm{Ni}$ (II) and $\mathrm{Cu}$ (II) ions were synthesized, characterized and thermally studied for the first time in this work.

\section{Materials and methods}

\subsection{Materials}


All Chemical reagents used were purchased from $\mathrm{BDH}$ and used as provided.

\subsection{Synthesis of the complexes}

Generally, the solid complexes were prepared by the same methodology previously described ${ }^{11}$. Briefly, an ethanolic solution of hydrated metal chloride $(0.01 \mathrm{~mol})$ was dropwise added in an ethanolic solution of the first ligand (urea $0.01 \mathrm{~mol}$ ) with stirring. The mixture was refluxed for $12 \mathrm{~h}$ with constant stirring. A hot solution of $0.01 \mathrm{~mol}$ glycine in 1:1 ethanol / water mixture ratio was dropwise added to the urea / metal mixture and drops of $1 \mathrm{~mol} \mathrm{~L}^{-1} \mathrm{NaOH}$ solution were used to adjust $\mathrm{pH} 7.0-7.5$ to deprotonate $\mathrm{NH}_{3}{ }^{+}$of the glycine to $\mathrm{NH}_{2}$. The mixture was refluxed for $2 \mathrm{~h}$ until resulting in the formation of a colored precipitate. The resulting product was filtered off and then washed with distilled water to remove $\mathrm{NaCl}$. The product was further washed with absolute ethanol/dimethylformamide (DMF) and left to dry. Acceptable yield percentage was obtained (52-66\%).

\subsection{Instrumentation}

Glass capillary tubes were used to measure the melting points of the metal complexes in degrees celsius on a Stuart Scientific electrothermal melting point apparatus. Silica Gel $\mathrm{GF}_{254}$ plates (mn-kieselgel G., $0.2 \mathrm{~mm}$ thickness) was used for TLC. Vario ELFab instrument was used for elemental analysis (carbon, hydrogen and nitrogen) of complexes. Chloride was volumetrically or gravimetrically determined by silver nitrate. The amount of water was determined gravimetrically using weight loss method and also from thermal analysis. Perkin-Elmer 2380 flame atomic absorption spectrophotometer was used to measure the metal content. Jenway conductivity meter model 4510 was used to measure the molar conductance of $10^{-3} \mathrm{~mol} \mathrm{~L}^{-1}$ solutions of the metal complexes in dimethylsulfoxide (DMSO) solvent. IR spectra of the metal complexes were measured by using FT/IR-140 (Jasco, Japan). A Varian FT$300 \mathrm{MHz}$ spectrometer in $\mathrm{d}_{6}$-DMSO solvent was used for obtaining proton ${ }^{1} \mathrm{HNMR}$ spectra, using TMS as internal standard. Mass spectra were recorded on a JEOL JMS600 spectrometer. The electronic spectra of the complexes were measured in the range 400-800 nm using an UV-VIS spectrophotometer Specord 200, Analytilk Jena (Germany). The mass susceptibility $\left(\chi_{\mathrm{g}}\right)$ of the solid complexes was measured at room temperature using Gouy's method on a magnetic susceptibility balance from Johnson Metthey and Sherwood model. Differential Thermal Analysis (DTA) and Thermogravimetric Analysis (TGA) were performed using the Shimadzu DTA-50 and Shimadzu TGA-50H thermal analyzers. The experiments were carried out in the temprature range from 25 to $800{ }^{\circ} \mathrm{C}$ under nitrogen atmosphere in a platinum pan, heating rate of $10{ }^{\circ} \mathrm{C} / \mathrm{min}$ and flow rate of $30 \mathrm{~mL} \mathrm{~min}^{-1}$. The antibacterial activity against four species of bacteria (Staphylococcus aureus, Bacillus spp., Escherichia coli and Pseudomonas aeruginosa) was tested by agar diffusion method. $1000 \mu \mathrm{g} \mathrm{mL}^{-1}$ concentration for each of these compounds were individually prepared in DMSO, then the filter paper disc (whatman No.1.5 mm diameter) was saturated with the solution of these compounds. The discs were placed on the surface of Millar Hinton agar dishes seeded with the strains of bacteria. The inhibition zones $(\mathrm{mm})$ were measured after $24 \mathrm{~h}$ at $37{ }^{\circ} \mathrm{C}$. DMSO and gentamicin $\left(120 \mu \mathrm{g} \mathrm{mL}^{-1}\right)$ were used as control and reference, respectively.

\section{Results and discussion}

Complexes of $\mathrm{Co}(\mathrm{II}), \mathrm{Ni}(\mathrm{II})$ and $\mathrm{Cu}(\mathrm{II})$ with urea (ur) and glycine (gly) ligands have been prepared and characterized. Analytical data, physical properties, molar conductivity, and composition of the synthesized complexes are given in Tables 1 and 2 . The molar conductivity values $\left(135-149 \mathrm{~S} \mathrm{~cm}^{2} \mathrm{~mol}^{-1}\right)$ reflect the electrolytic properties of these complexes. The single spot appearance in the TLC proves the purity of these complexes. 
Table 1. Some physical properties of the complexes.

\begin{tabular}{|c|c|c|c|c|c|}
\hline \multirow[b]{2}{*}{$\begin{array}{l}\text { Complex Proposed } \\
\text { Formula }\end{array}$} & \multirow[b]{2}{*}{ Color } & \multirow[b]{2}{*}{ M.p $/{ }^{\circ} \mathbf{C}$} & \multicolumn{2}{|c|}{ TLC } & \multirow[b]{2}{*}{$\begin{array}{l}\text { molar conductivity } \\
\Lambda_{\mathrm{m}} / \mathrm{S} \mathrm{cm}^{2} \mathrm{~mol}^{-1}\end{array}$} \\
\hline & & & $\begin{array}{l}\text { No.of } \\
\text { spots }\end{array}$ & $\mathbf{R f}$ & \\
\hline $\begin{array}{c}{\left[\mathrm{Co}(\text { ur })(\text { gly })\left(\mathrm{H}_{2} \mathrm{O}\right)_{2}\right] \mathrm{Cl}} \\
{\left[\mathrm{Co}\left(\mathrm{C}_{3} \mathrm{H}_{12} \mathrm{~N}_{3} \mathrm{O}_{5}\right)\right] \mathrm{Cl}}\end{array}$ & $\begin{array}{c}\text { dark } \\
\text { violet }\end{array}$ & $>350$ & One & 0.28 & 149 \\
\hline $\begin{array}{c}{\left[\mathrm{Ni}(\mathrm{ur})(\mathrm{gly})\left(\mathrm{H}_{2} \mathrm{O}\right)_{2}\right] \mathrm{Cl}} \\
{\left[\mathrm{Ni}\left(\mathrm{C}_{3} \mathrm{H}_{12} \mathrm{~N}_{3} \mathrm{O}_{5}\right)\right] \mathrm{Cl}}\end{array}$ & $\begin{array}{l}\text { pale } \\
\text { green }\end{array}$ & $226 \pm 1$ & One & 0.39 & 135 \\
\hline $\begin{array}{c}{\left[\mathrm{Cu}(\mathrm{ur})(\text { gly })\left(\mathrm{H}_{2} \mathrm{O}\right)_{2}\right] \mathrm{Cl}} \\
{\left[\mathrm{Cu}\left(\mathrm{C}_{3} \mathrm{H}_{12} \mathrm{~N}_{3} \mathrm{O}_{5}\right)\right] \mathrm{Cl}}\end{array}$ & $\begin{array}{l}\text { light } \\
\text { blue }\end{array}$ & $>350$ & One & 0.39 & 148 \\
\hline
\end{tabular}

Table 2. Elemental analysis of the complexes.

\begin{tabular}{|c|c|c|c|c|c|c|c|c|c|c|c|c|}
\hline \multirow{2}{*}{$\begin{array}{c}\text { Complex proposed } \\
\text { formula }\end{array}$} & \multicolumn{2}{|c|}{ Molar mass } & \multicolumn{9}{|c|}{ Elemental analysis } \\
\cline { 2 - 13 } & calc. & found & calc. & found & calc. & found & calc. & found & calc. & found & calc. & found \\
\hline $\begin{array}{c}{\left[\mathrm{Co}(\mathrm{ur})(\mathrm{gly})\left(\mathrm{H}_{2} \mathrm{O}\right)_{2}\right] \mathrm{Cl}} \\
{\left[\mathrm{Co}\left(\mathrm{C}_{3} \mathrm{H}_{12} \mathrm{~N}_{3} \mathrm{O}_{5}\right)\right] \mathrm{Cl}}\end{array}$ & 264.53 & 264.03 & 13.62 & 13.65 & 4.57 & 4.58 & 15.89 & 15.91 & 22.28 & 22.32 & 13.40 & 13.45 \\
\hline $\begin{array}{c}{\left[\mathrm{Ni}(\mathrm{ur})(\mathrm{gly})\left(\mathrm{H}_{2} \mathrm{O}\right)_{2}\right] \mathrm{Cl}} \\
{\left[\mathrm{Ni}\left(\mathrm{C}_{3} \mathrm{H}_{12} \mathrm{~N}_{3} \mathrm{O}_{5}\right)\right] \mathrm{Cl}}\end{array}$ & 264.29 & 264.34 & 13.63 & 13.63 & 4.58 & 4.58 & 15.90 & 15.90 & 22.21 & 22.20 & 13.41 & 13.43 \\
\hline $\begin{array}{c}{\left[\mathrm{Cu}(\mathrm{ur})(\mathrm{gly})\left(\mathrm{H}_{2} \mathrm{O}\right)_{2}\right] \mathrm{Cl}} \\
{\left[\mathrm{Cu}\left(\mathrm{C}_{3} \mathrm{H}_{12} \mathrm{~N}_{3} \mathrm{O}_{5}\right)\right] \mathrm{Cl}}\end{array}$ & 269.14 & 269.19 & 13.38 & 13.39 & 4.49 & 4.49 & 15.61 & 15.61 & 23.61 & 23.61 & 13.17 & 13.17 \\
\hline
\end{tabular}

\subsection{IR spectra of urea - glycine complexes}

The coordination sites of urea and glycine ligands in their complexes were investigated. The infrared spectra show that urea acts as a neutral bidentate ligand through $\mathrm{C}=\mathrm{O}$ and $\mathrm{NH}_{2}$ groups while glycine behaves as a bidentate anion ligand through $\mathrm{COO}^{-}$and $\mathrm{NH}_{2}$ groups. IR spectra of ureaglycine complexes are represented in Figures 1,2 and 3. Assignments of the characteristic bands are summarized in Table 3. As it was postulated, the metal complexes were quite different when compared with the free ligands.

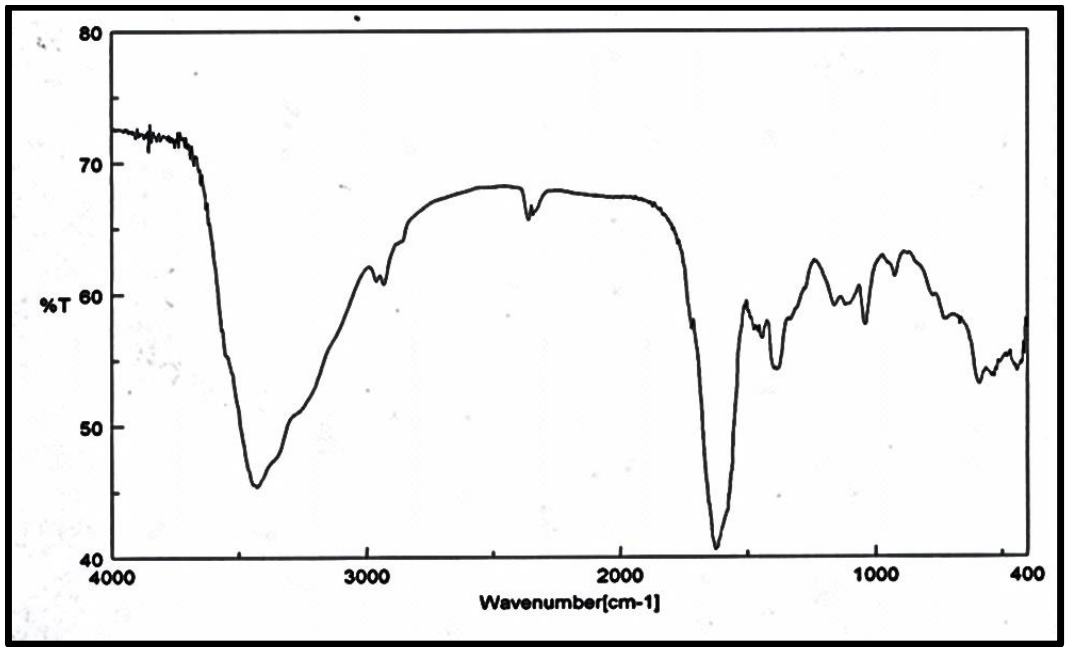

Figure 1. IR spectrum of $\left[\mathrm{Co}(\mathrm{ur})(\mathrm{gly})\left(\mathrm{H}_{2} \mathrm{O}\right)_{2}\right] \mathrm{Cl}$ complex. 


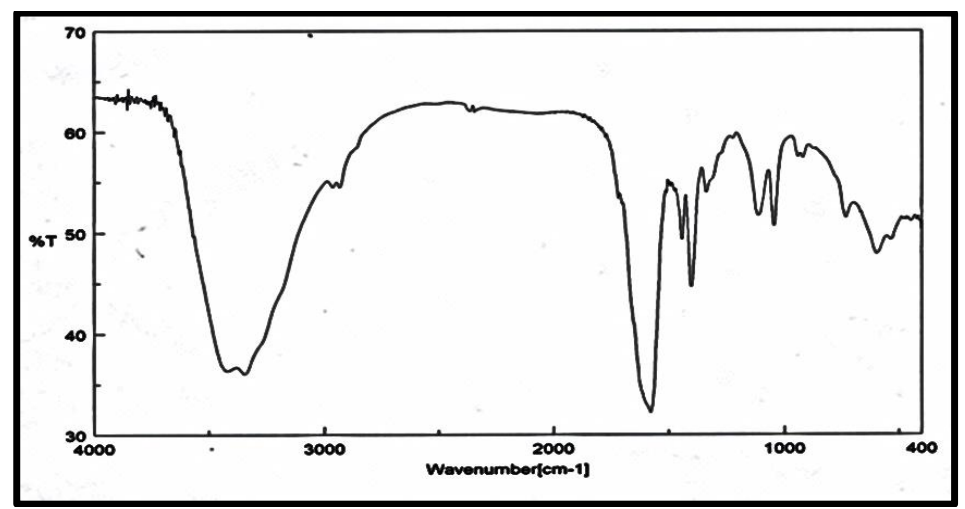

Figure 2. IR spectrum of $\left[\mathrm{Ni}(\mathrm{ur})(\mathrm{gly})\left(\mathrm{H}_{2} \mathrm{O}\right)_{2}\right] \mathrm{Cl}$ complex.

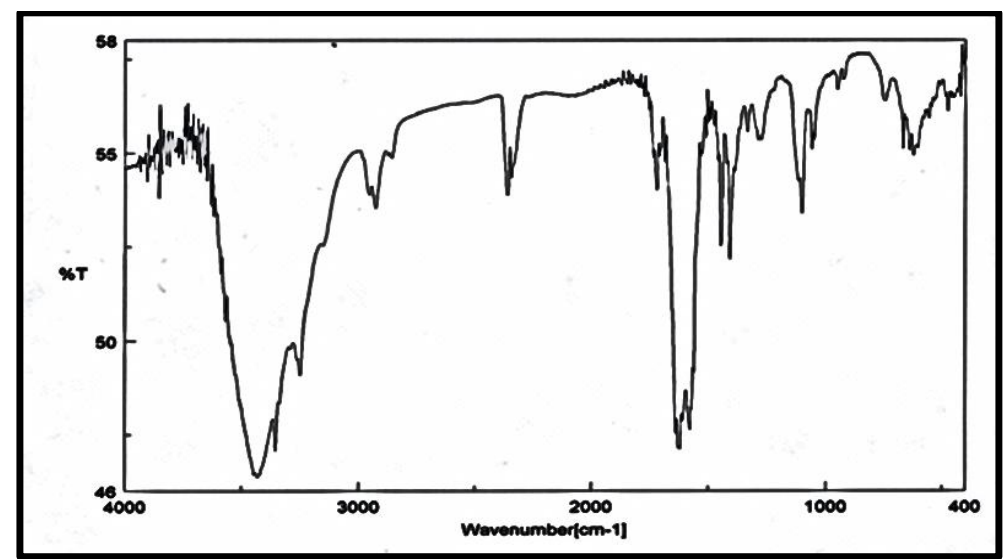

Figure 3. IR spectrum of $\left[\mathrm{Cu}(\mathrm{ur})(\mathrm{gly})\left(\mathrm{H}_{2} \mathrm{O}\right)_{2}\right] \mathrm{Cl}$ complex. 
Table 3. Main IR bands $\left(\mathrm{cm}^{-1}\right)$ of the urea-glycine complexes

\begin{tabular}{|c|c|c|c|c|c|}
\hline Urea & Glycine & {$\left[\mathrm{Co}(\mathrm{ur})(\mathrm{gly})\left(\mathrm{H}_{2} \mathrm{O}\right)_{2}\right] \mathrm{Cl}$} & {$\left[\mathrm{Ni}(\mathrm{ur})(\mathrm{gly})\left(\mathrm{H}_{2} \mathrm{O}\right)_{2}\right] \mathrm{Cl}$} & {$\left[\mathrm{Cu},(\mathrm{ur})(\mathrm{gly})\left(\mathrm{H}_{2} \mathrm{O}\right)_{2}\right] \mathrm{Cl}$} & Assignment \\
\hline- & $3164-3007 \mathrm{br}$ & - & - & - & $v\left(\mathrm{NH}_{3}^{+}\right)$ \\
\hline $3353 \mathrm{~m}$ & - & $\begin{array}{l}\mathrm{ur}-3250 \mathrm{br} \\
\text { gly-3185w,br }\end{array}$ & $\begin{array}{c}\text { ur-3270br } \\
\text { gly }-3168 w, b r\end{array}$ & $\begin{array}{l}\text { ur }-3248 \mathrm{br} \\
\text { gly }-3160 \mathrm{br}\end{array}$ & $v_{5}\left(\mathrm{NH}_{2}\right)$ \\
\hline $3466 \mathrm{~m}$ & - & ur, gly - 3376br & ur,gly $-3346 \mathrm{~m}$ & $\begin{array}{l}\text { ur }-3355 \mathrm{~m} \\
\text { gly }-3290 w\end{array}$ & $v_{\text {as }}\left(\mathrm{NH}_{2}\right)$ \\
\hline $1618 \mathrm{br}$ & - & - & - & $1609 \mathrm{w}$ & $\delta(\mathrm{NH})$ \\
\hline- & $1410 \mathrm{~m}$ & $1397 \mathrm{~m}$ & $1402 \mathrm{~s}$ & $1408 \mathrm{~s}$ & $v_{5}\left(\mathrm{COO}^{-}\right)$ \\
\hline- & $1598 \mathrm{br}$ & $1509 w$ & $1578 \mathrm{~s}$ & $1578 \mathrm{~m}$ & $v_{a s}\left(\mathrm{COO}^{-}\right)$ \\
\hline $1695 \mathrm{w}$ & $1715 w$ & $\begin{array}{c}\mathrm{ur}-1625 \mathrm{~s} \\
\mathrm{gly}-1718 \mathrm{~m}\end{array}$ & $\begin{array}{l}\text { ur }-1680 w \\
\text { gly }-1718 w\end{array}$ & $\begin{array}{l}\text { ur }-1618 \mathrm{~m} \\
\text { gly-1719m }\end{array}$ & $v(\mathrm{CO})$ \\
\hline $1468 \mathrm{br}$ & $1033 \mathrm{~s}$ & $\begin{array}{l}\text { ur }-1474 w \\
\text { gly }-1040 \mathrm{~m}\end{array}$ & $\begin{array}{l}\text { ur }-1475 w \\
\text { gly }-1045 \mathrm{~m}\end{array}$ & $\begin{array}{r}\text { ur }-1475 w \\
\text { gly }-1050 w\end{array}$ & $v(\mathrm{CN})$ \\
\hline- & $2892 \mathrm{br}$ & $2885 \mathrm{br}$ & $2863 \mathrm{w} \cdot \mathrm{br}$ & $2857 \mathrm{br}$ & $v\left(\mathrm{CH}_{2}\right)$ \\
\hline- & $1442 \mathrm{~m}$ & $1439 \mathrm{~m}$ & $1441 \mathrm{~s}$ & $1446 \mathrm{~s}$ & $\delta\left(\mathrm{CH}_{2}\right)$ \\
\hline- & - & $3431 \mathrm{br}$ & $3422 \mathrm{br}$ & $3432 \mathrm{br}$ & $\mathrm{H}_{2} \mathrm{O} v(\mathrm{OH})$ \\
\hline- & - & $451 w$ & $483 \mathrm{w}$ & $475 \mathrm{w}$ & $v(\mathrm{M}-\mathrm{O})$ \\
\hline- & - & $440 w$ & $460 \mathrm{w}$ & $421 \mathrm{w}$ & $v(\mathrm{M}-\mathrm{N})$ \\
\hline
\end{tabular}

$\mathrm{s}=$ strong, $\mathrm{m}=$ medium,$\quad \mathrm{br}=$ broad, $\mathrm{w}=$ weak $, \mathrm{w}, \mathrm{br}=$ weak and broad

The infrared spectral data of the complexes are as follows:

(1) All the complexes spectra show a broad band at $3422-3432 \mathrm{~cm}^{-1}$ that corresponds to the stretching mode of water existing in the complexes as identified by thermal and elemental analysis. The coordinated water is identified by the appearance of $\rho_{\mathrm{r}}$ (rocking) and $\rho_{\mathrm{w}}$ (wagging) at 925 $\mathrm{cm}^{-1}$ and $511 \mathrm{~cm}^{-1}$, respectively ${ }^{12}$.

(2) The amino groups of urea show lower-shift of $123-103 \mathrm{~cm}^{-1}$ and of $120-90 \mathrm{~cm}^{-1}$ for symmetrical and asymmetrical stretching $v\left(\mathrm{NH}_{2}\right)$ frequencies, respectively. This strongly suggests that the nitrogen atom of amino group must be involved in complexation, and the appearance of a new band in the range of $406-460 \mathrm{~cm}^{-1}$, assigned to $v(\mathrm{M}-\mathrm{N})$ vibration, confirms this proposition ${ }^{13,14}$.

(3) A new band at $1680-1618 \mathrm{~cm}^{-1}$ is attributed to $v(\mathrm{CO})$ from urea, assigned to $v(\mathrm{C}=\mathrm{O}-\mathrm{M})$.

(4) The characteristic bands in complexes spectra occur in the ranges $3185-3160 \mathrm{~cm}^{-1}$ and $3376-3290 \mathrm{~cm}^{-1}$ for symmetrical and asymmetrical $v\left(\mathrm{NH}_{2}\right)$ group of glycine, respectively, which appears at lower wave number than the free $v\left(\mathrm{NH}_{2}\right)$. Hence, coordination through nitrogen of the amino group is involved ${ }^{15}$.
(5) The symmetrical $v\left(\mathrm{COO}^{-}\right)$and asymmetrical $v\left(\mathrm{COO}^{-}\right)$vibrations of glycine shift by $13-8 \mathrm{~cm}^{-1}$ and $89-20 \mathrm{~cm}^{-1}$, respectively. This confirms that carboxylate is acting as a monodentate group ${ }^{16}$. Glycine acts as monobasic bidentate, through the nitrogen of amino and oxygen of carboxylate groups in these complexes ${ }^{17,18}$.

(6) The IR spectra in the range $483-451 \mathrm{~cm}^{-1}$ and $460-421 \mathrm{~cm}^{-1}$ show bands of low intensity due to stretching vibrations of $v(\mathrm{M}-\mathrm{O})$ and $\mathrm{v}(\mathrm{M}-\mathrm{N})$, respectively ${ }^{13,14}$.

\section{2. ${ }^{1}$ HNMR spectra of urea-glycine complexes}

Complexes were investigated by using ${ }^{1} \mathrm{HNMR}$ spectra in $\mathrm{d}_{6}-\mathrm{DMSO}$ and TMS (tetramethyl silane) as standard and data are in Table 4. $\left[\mathrm{Co}(\mathrm{ur})(\mathrm{gly})\left(\mathrm{H}_{2} \mathrm{O}\right)_{2}\right] \mathrm{Cl},\left[\mathrm{Ni}(\mathrm{ur})(\mathrm{gly})\left(\mathrm{H}_{2} \mathrm{O}\right)_{2}\right] \mathrm{Cl}$ and $\left[\mathrm{Cu}(\mathrm{ur})(\mathrm{gly})\left(\mathrm{H}_{2} \mathrm{O}\right)_{2}\right] \mathrm{Cl}$ complexes show signals in the range 5.4-7.2 ppm attributed to the amide group of urea ${ }^{19,20}$. The methylene group of glycine $\left(-\mathrm{CH}_{2-}\right)$ in $\mathrm{Co}(\mathrm{II}), \mathrm{Ni}(\mathrm{II})$ and $\mathrm{Cu}(\mathrm{II})$ complexes absorbs near 3.2, 3.2 and $3.1 \mathrm{ppm}$, respectively. $\mathrm{NH}_{2}$ group shows signals at 2.9, 2.5 and $2.6 \mathrm{ppm}$, respectively ${ }^{21,22}$. In urea, one amine and the carbonyl groups are coordinated to the central metal ion without displacement of $\mathrm{NH}_{2}$ proton, 
while in glycine presents a new signal in the range 2.5-2.9 ppm because of the deprotonation of $\mathrm{NH}^{3+}$ to $\mathrm{NH}_{2}$. The appearance of a new signal around 3.5-
$3.8 \mathrm{ppm}$ confirms the presence of water molecules in the complexes ${ }^{23}$.

Table 4. ${ }^{1} \mathrm{HNMR}$ chemical shift (ppm) of free urea and glycine ligands and of complexes.

\begin{tabular}{|c|c|c|c|c|c|}
\hline System & $\begin{array}{c}(\mathrm{CH})_{\alpha} \\
\alpha=\mathrm{Alpha}\end{array}$ & $\mathrm{NH}_{3}{ }^{+}$ & $\mathrm{NH}_{2 \text { (gly) }}$ & $\mathrm{NH}_{2 \text { (ur) }}$ & $\mathrm{H}_{2} \mathrm{O}$ \\
\hline urea & - & - & - & $6-7.5$ & - \\
\hline glycine & 3.5 & $8-7$ & - & - & - \\
\hline$\left[\mathrm{Co}(\right.$ ur $\left.)(\mathrm{gly})\left(\mathrm{H}_{2} \mathrm{O}\right)_{2}\right] \mathrm{Cl}$ & 3.2 & - & 2.9 & $\begin{array}{c}5.4_{\text {(bonding) }} \\
6.4_{\text {(nonbonding) }}\end{array}$ & 3.8 \\
\hline$\left[\mathrm{Ni}(\right.$ ur $\left.)(\mathrm{gly})\left(\mathrm{H}_{2} \mathrm{O}\right)_{2}\right] \mathrm{Cl}$ & 3.2 & - & 2.5 & $\begin{array}{c}4.7_{\text {(bonding) }} \\
7.2_{\text {(nonbonding) }}\end{array}$ & 3.7 \\
\hline$\left[\mathrm{Cu}(\right.$ ur $\left.)(\mathrm{gly})\left(\mathrm{H}_{2} \mathrm{O}\right)_{2}\right] \mathrm{Cl}$ & 3.1 & - & 2.6 & $\begin{array}{c}5.5_{\text {(bonding) }} \\
7_{\text {(nonbonding) }}\end{array}$ & 3.5 \\
\hline
\end{tabular}

\subsection{Mass spectra of urea-glycine complexes}

The mass spectra of $\mathrm{Co}(\mathrm{II}), \mathrm{Ni}(\mathrm{II})$ and $\mathrm{Cu}(\mathrm{II})$ complexes with urea and glycine reveal molecular ion peaks at $\mathrm{m} / \mathrm{z}$ (calc. 264.53, found $264.03(4 \%)$ ), (calc. 264.29, found $264.34(11 \%)$ ) and (calc. 269.14 , found $269.19(9 \%))$, respectively.

The molecular ion of $\left[\mathrm{Co}(\mathrm{ur})(\mathrm{gly})\left(\mathrm{H}_{2} \mathrm{O}\right)_{2}\right] \mathrm{Cl}$ complex loses glycinate $\left(\mathrm{NH}_{2} \mathrm{CH}_{2} \mathrm{COO}^{-}\right)$ion and $2 \mathrm{H}_{2}$ leaving an ion at $\mathrm{m} / \mathrm{z} 185.67$, which by its turn, loses $\mathrm{H}_{2} \mathrm{O}, \mathrm{Cl}, \mathrm{CO}, \mathrm{NH}_{3}$ and $\mathrm{H}_{2}$ giving an ion at $\mathrm{m} / \mathrm{z}$ 85.01.

The mass spectrum of $\left[\mathrm{Ni}(\mathrm{ur})(\mathrm{gly})\left(\mathrm{H}_{2} \mathrm{O}\right)_{2}\right] \mathrm{Cl}$ complex exhibited a peak at $\mathrm{m} / \mathrm{z} 244.90$, indicating the loss of $\mathrm{H}_{2}$ and $\mathrm{NH}_{3}$, then this molecular ion loses $\mathrm{H}_{2} \mathrm{O}$ and $1 / 2 \mathrm{Cl}_{2}$ leaving an ion at $\mathrm{m} / \mathrm{z} 192.83$, which further loses one more $\mathrm{H}_{2} \mathrm{NCH}_{2} \mathrm{COO}^{-}$ affording an ion at $\mathrm{m} / \mathrm{z} 118.87$. The complex $\left[\mathrm{Cu}(\right.$ ur $\left.)(\mathrm{gly})\left(\mathrm{H}_{2} \mathrm{O}\right)_{2}\right] \mathrm{Cl}$ loses $\left[\mathrm{CO}, 1 / 2 \mathrm{Cl}_{2}\right]$ and $\mathrm{H}_{2} \mathrm{O}$ to give ions at $\mathrm{m} / \mathrm{z} 205.68$ and 251.19 , respectively.

\subsection{Electronic and magnetic spectral analysis}

The magnetic moments of the $\mathrm{Co}(\mathrm{II}), \mathrm{Ni}(\mathrm{II})$ and $\mathrm{Cu}$ (II) complexes as well as their electronic spectra data have provided good evidence for the structures of these complexes as shown in Table 5. $\left[\mathrm{Co}(\mathrm{ur})(\mathrm{gly})\left(\mathrm{H}_{2} \mathrm{O}\right)_{2}\right] \mathrm{Cl}$ hexa-coordination is suggested. This is based on the spectrum (Figure 5) recorded in DMSO solution which shows bands at $17985 \mathrm{~cm}^{-1}$ and $14482 \mathrm{~cm}^{-1}$, due to transition of ${ }^{4} \mathrm{~T}_{1 \mathrm{~g}} \rightarrow{ }^{4} \mathrm{~T}_{1 \mathrm{~g}}(\mathrm{P}) \quad$ (v3) and ${ }^{4} \mathrm{~T}_{1 \mathrm{~g}} \rightarrow{ }^{4} \mathrm{~A}_{2 \mathrm{~g}} \quad$ (v2), respectively ${ }^{23}$. The third band of the spectrum, assigned to $v 1$, could not be observed due to the limited range of the used instrument (200$1100 \mathrm{~nm})$. [Co(ur) (gly) $\left.\left(\mathrm{H}_{2} \mathrm{O}\right)_{2}\right] \mathrm{Cl}$ has a magnetic moments of 4.76 B.M; this value is due to a highspin octahedral geometry around the $\mathrm{Co}$ (II) ion as reported previously ${ }^{24}$. Moreover, the violet colour of octahedral $\mathrm{Co}$ (II) complexes is in good agreement with those previously reported ${ }^{25}$. 
Table 5. Magnetic moment and electronic spectral data in DMSO solution for the complexes.

\begin{tabular}{|c|c|c|c|c|}
\hline complex & $\begin{array}{l}\mu_{\text {eff }} / \\
\text { B.M }\end{array}$ & $\begin{array}{l}\text { charge transfer } \\
\text { bands } / \mathrm{cm}^{-1}\end{array}$ & $\begin{array}{l}d-d \text { transition bands / } \\
\mathrm{cm}^{-1}\end{array}$ & $\begin{array}{l}\text { proposed } \\
\text { structure }\end{array}$ \\
\hline$\left[\mathrm{Co}\right.$ (ur) (gly) $\left.\left(\mathrm{H}_{2} \mathrm{O}\right)_{2}\right] \mathrm{Cl}$ & 4.76 & 23697 & 17985,14492 & octahedral \\
\hline$\left[\mathrm{Ni}(\mathrm{ur})(\mathrm{gly})\left(\mathrm{H}_{2} \mathrm{O}\right)_{2}\right] \mathrm{Cl}$ & 3.2 & 23419 & $\begin{array}{c}21459,14970 \\
13477\end{array}$ & octahedral \\
\hline$\left[\mathrm{Cu}(\right.$ ur $)($ gly $\left.)\left(\mathrm{H}_{2} \mathrm{O}\right)_{2}\right] \mathrm{Cl}$ & 1.43 & 24272 & 12987 & $\begin{array}{c}\text { distorted } \\
\text { octahedral }\end{array}$ \\
\hline
\end{tabular}

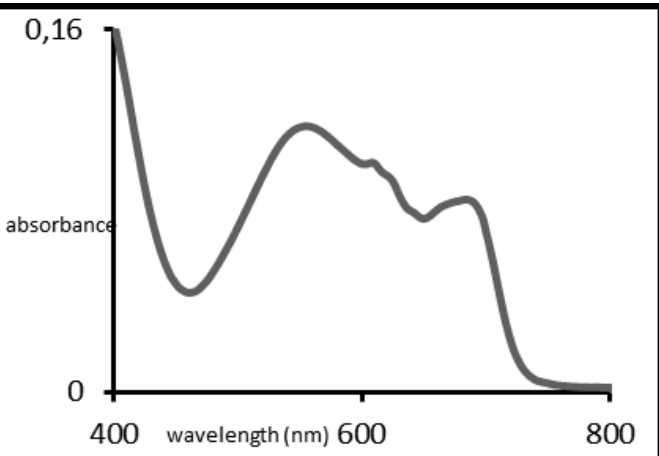

Figure 4. UV-VIS spectrum of $\left[\mathrm{Co}(\mathrm{ur})(\mathrm{gly})\left(\mathrm{H}_{2} \mathrm{O}_{2}\right] \mathrm{Cl}\right.$ complex in the MSO solution.

From the above discussion (Figure 5) of $\left[\mathrm{Co}(\mathrm{ur})(\mathrm{gly})\left(\mathrm{H}_{2} \mathrm{O}_{2}\right] \mathrm{Cl}\right.$ can be suggested. Furthermore, previous studies proved that the broad bands centred at $23697 \mathrm{~cm}^{-1}$ should be assigned to charge-transfer transitions in $\left[\mathrm{Co}(\mathrm{ur})(\mathrm{gly})\left(\mathrm{H}_{2} \mathrm{O}\right)_{2}\right] \mathrm{Cl}^{26}$.
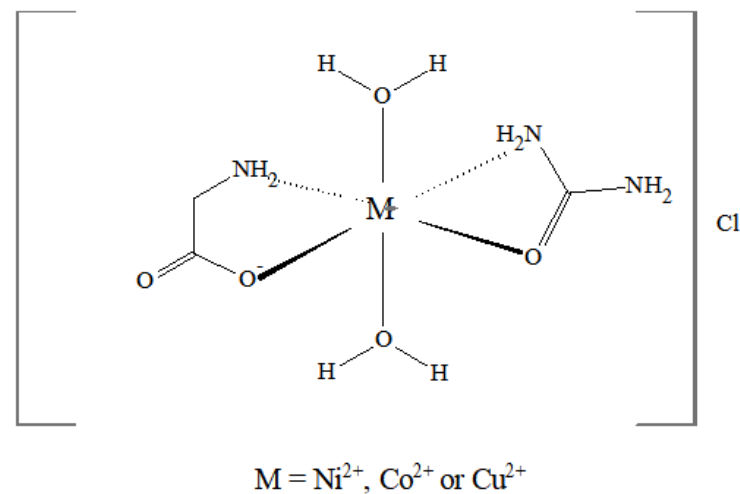

Figure 5. Suggested structure for the complex.

The magnetic moment data as well as the electronic spectrum data of the nickel complex are given in Table 5. The complex
$\left[\mathrm{Ni}(\right.$ ur $)($ gly $\left.)\left(\mathrm{H}_{2} \mathrm{O}\right)_{2}\right] \mathrm{Cl}$ has a magnetic moment value of 3.2 B.M consistent with an octahedral geometry around the $\mathrm{Ni}$ (II) ion with a ${ }^{3} A_{2 \mathrm{~g}}$ ground term, which lies in the range reported in the literature ${ }^{27}$. In addition, the complex has three bands in the UV-VIS recorded in DMSO solution (Figure 6): $21459 \mathrm{~cm}^{-1}$ may be due to the ${ }^{3} A_{2 \mathrm{~g}} \rightarrow{ }^{3} T_{1 \mathrm{~g}}$ (v3); $14970 \mathrm{~cm}^{-1}$ due to ${ }^{3} A_{2 \mathrm{~g}} \rightarrow{ }^{3} T_{1 \mathrm{~g}}$ (v2); $13477 \mathrm{~cm}^{-1}$ in the transition range of an octahedral structure around the $\mathrm{Ni}(\mathrm{II})$ ion (v1) (Figure 5) ${ }^{28}$. The green colour is also an additional evidence for the octahedral structure ${ }^{26}$. The band at $23419 \mathrm{~cm}^{-1}$ may be attributed to the charge transfer transition of $\left[\mathrm{Ni}(\mathrm{ur})(\mathrm{gly})\left(\mathrm{H}_{2} \mathrm{O}\right)_{2}\right] \mathrm{Cl}$ complex ${ }^{23}$.

$\left[\mathrm{Cu}(\mathrm{ur})(\mathrm{gly})\left(\mathrm{H}_{2} \mathrm{O}\right)_{2}\right] \mathrm{Cl}$ (structure in Figure 5) has an electronic spectrum (Figure 7) that shows a strong band at $12987 \mathrm{~cm}^{-1}$ due to ${ }^{2} E_{\mathrm{g}} \rightarrow{ }^{2} T_{2 \mathrm{~g}}$ transition, suggesting a distorted octahedral geometry ${ }^{26}$. The broadness in the band may be due to Jahn-Teller effect ${ }^{29}$ and the proposed geometry is also supported by the blue colour of this complex $^{27}$. The magnetic moment value of this complex 1.43 B.M agrees with the $d^{9}$ system containing one unpaired electron ${ }^{26}$. The observed band at $24272 \mathrm{~cm}^{-1}$ in the spectrum of the complex may be due to LMCT $(\mathrm{L} \rightarrow \mathrm{M}$ charge transfer transition) of $\left[\mathrm{Cu}(\mathrm{ur})(\mathrm{gly})\left(\mathrm{H}_{2} \mathrm{O}\right)_{2}\right] \mathrm{Cl}$ complex ${ }^{30}$. 


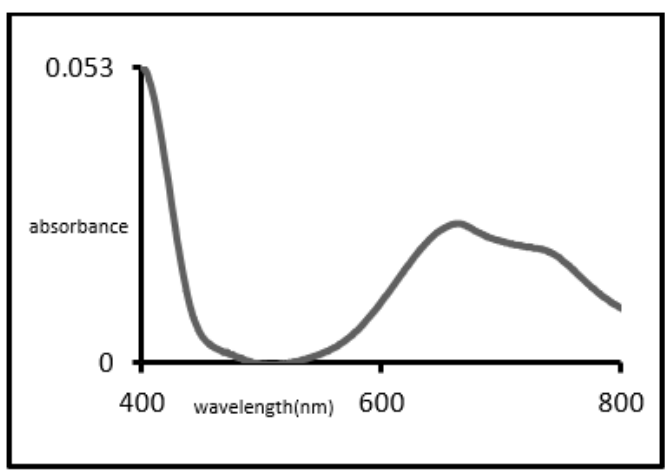

Figure 6. UV-VIS spectrum of $\left[\mathrm{Ni}(\mathrm{ur})(\mathrm{gly})\left(\mathrm{H}_{2} \mathrm{O}\right)_{2}\right] \mathrm{Cl}$ complex in DMSO solution.

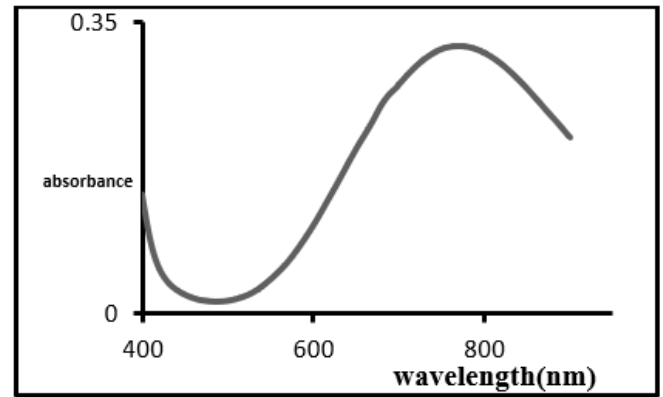

Figure 7. UV-VIS spectrum of $\left[\mathrm{Cu}(\mathrm{ur})(\mathrm{gly})\left(\mathrm{H}_{2} \mathrm{O}\right)_{2}\right] \mathrm{Cl}$ complex in DMSO solution.

\subsection{Thermal analysis of Cu-urea-glycine complex}

The thermal and kinetic parameters for each step in the decomposition sequences of the $\mathrm{Cu}$ complex were determined by using the integral Coast-Redfern equation. The Coats-Redfern method is linearized for a correctly-chosen order of reaction $(n)$ and the activation energy $\left(E_{a}\right)$ is obtained from the slope of the $\log [y]$ versus $T^{-1}$ plot from Equation:

$$
\begin{aligned}
\log \left[\frac{1-(1-\alpha)^{1-n}}{T^{2}(1-n)}\right] & \\
& =\log \left[\frac{Z R}{q E_{a}}\left(1-\frac{2 R T}{E_{a}}\right)\right] \\
& -\frac{E_{a}}{2.303 R T} \text { for } n \neq 1 \quad \rightarrow 1
\end{aligned}
$$

where: $\alpha=$ fraction of mass loss, $T=$ temperature (K), $Z=$ pre-exponential factor, $R=$ molar gas constant, $q=$ heating rate and $n=$ reaction order; estimated by Horovitz-Metzger method.

The thermodynamic parameters of the thermal degradation step: enthalpy $\left(\Delta \mathrm{H}^{*}\right)$, entropy $\left(\Delta \mathrm{S}^{*}\right)$, and Gibbs energy $\left(\Delta G^{*}\right)$ of activation are calculated using the following standard equations:

$$
\Delta S^{*}=R \ln \frac{Z h}{k T_{\max }}
$$

$$
\begin{gathered}
\Delta H^{*}=E_{a}-R T_{\max } \\
\Delta G^{*}=\Delta H^{*}-T_{\max } \Delta S^{*}
\end{gathered}
$$

where $z, k$, and $h$ are the pre-exponential factor, Boltzmann and Planck constant, respectively.

The TG and DTA thermograms of $\left[\mathrm{Cu}\left(\right.\right.$ ur) $\left(\right.$ gly) $\left.\left(\mathrm{H}_{2} \mathrm{O}\right)_{2}\right] \mathrm{Cl}$ complex (Figures 8 and 9) are characterized by the three fast decomposition steps $\left(25-318,318-361\right.$ and $\left.361-375^{\circ} \mathrm{C}\right)$. The $\mathrm{T}_{\mathrm{DTG}}$ at $302{ }^{\circ} \mathrm{C}$ is consistent with the evolution of $100 \%$ of coordinated water, $100 \%$ of bonded chloride and $60 \%$ the urea ligand (calc. $39.95 \%$, found $39.93 \%$ ). The activation energy calculated is $89 \mathrm{~kJ} \mathrm{~mol}^{-1}$ (Table 6). The remaining urea molecule may be eliminated in the second step together with $52.72 \%$ of glycine molecule (calc. and found $23.43 \%$ ). In this step $\left(318-361{ }^{\circ} \mathrm{C}\right)$, the activation energy is $123 \mathrm{~kJ} \mathrm{~mol}^{-1}$ and the order of decomposition reaction is 3.6 with the apparent $\mathrm{T}_{\mathrm{DTG}}\left(334^{\circ} \mathrm{C}\right)$ and the exothermic $\left(\mathrm{T}_{\mathrm{DTA}}\right)$ peak at $349{ }^{\circ} \mathrm{C}$ (Table 7). The third step, which corresponds to $17.57 \%$ loss of glycine molecule (calc. 4.86 , found $4.84 \%$ ) has an activation energy of $117 \mathrm{~kJ} \mathrm{~mol}^{-1}$. The final residue is $\mathrm{CuO}$ and $0.5 \mathrm{C}$ as ash $[(\mathrm{O}=21.6 \%$ gly, $\mathrm{C}=8.11 \% \mathrm{gly}$ ) (calc. and found $31.78 \%$ )]. The $\Delta \mathrm{S}^{*}$, $\Delta \mathrm{H}^{*}$ and $\Delta \mathrm{G}^{*}$ for these three steps are calculated $\left(-119.3,-100.1\right.$ and $\left.-183.8 \mathrm{~J} \mathrm{~K}^{-1} \mathrm{~mol}^{-1}\right),(86.5,120.2$ and $\left.114 \mathrm{~kJ} \mathrm{~mol}^{-1}\right)$ and $(122.5,153.6$ and $\left.180.7 \mathrm{~kJ} \mathrm{~mol}^{-1}\right)$, respectively.

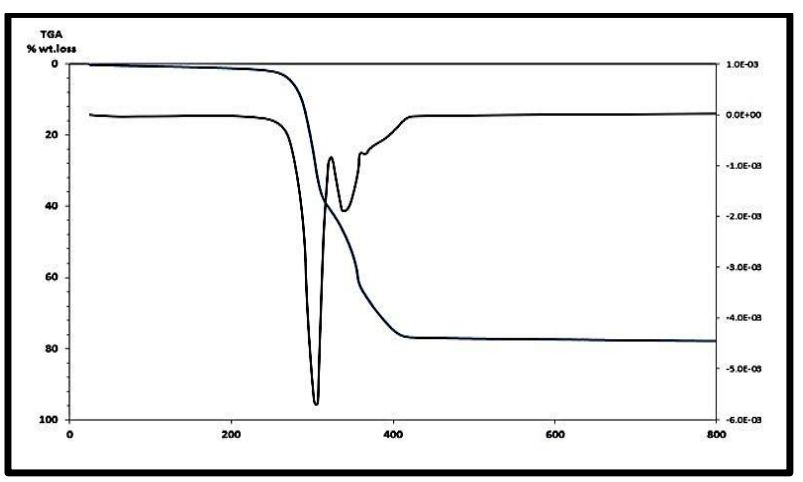

Figure 8. TG and DTG curves of $\left[\mathrm{Cu}(\mathrm{ur})(\mathrm{gly})\left(\mathrm{H}_{2} \mathrm{O}\right)_{2}\right] \mathrm{Cl}$.

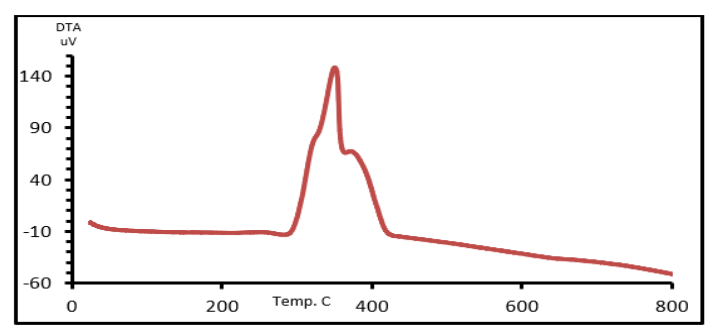

Figure 9. DTA curve of $\left[\mathrm{Cu}(\mathrm{ur})(\mathrm{gly})\left(\mathrm{H}_{2} \mathrm{O}\right)_{2}\right] \mathrm{Cl}$. 
Table 6. Characteristic parameters of thermal decomposition $\left(10^{\circ} \mathrm{C} \mathrm{min}^{-1}\right)$ for $\left[\mathrm{Cu}(\mathrm{ur})(\mathrm{gly})\left(\mathrm{H}_{2} \mathrm{O}\right)_{2}\right] \mathrm{Cl}$.

\begin{tabular}{|c|c|c|c|c|c|c|c|c|}
\hline \multirow{2}{*}{ Comp. } & \multirow{2}{*}{ Step } & \multicolumn{4}{|c|}{ TGA } & \multicolumn{2}{|c|}{ DTA } & \multirow{2}{*}{ mass loss } \\
\hline & & $\begin{array}{l}\text { found } \\
\text { (calc.) }\end{array}$ & $\mathbf{T}_{i} / \mathbf{C}^{\circ}$ & $\mathbf{T}_{\mathrm{f}} / \mathbf{C}^{\circ}$ & $\mathbf{T}_{\mathrm{DTG}}$ & $\mathbf{T}_{\mathrm{DTA}}$ & Heat & \\
\hline \multirow{3}{*}{ 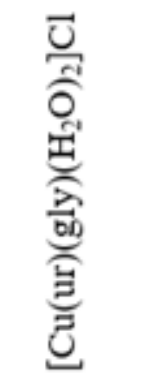 } & 1 & $\begin{array}{c}39.93 \\
(39.95)\end{array}$ & 25 & 318 & 3.2 & 323 & exo & $\begin{array}{l}-\left[100 \% \mathrm{H}_{2} \mathrm{O}+\right. \\
100 \% \mathrm{Cl}+60 \% \mathrm{ur}]\end{array}$ \\
\hline & 2 & $\begin{array}{c}23.43 \\
(23.43)\end{array}$ & 318 & 361 & 334 & 349 & exo & $\begin{array}{l}-[40 \% \text { ur }+52.72 \% \\
\text { gly] }\end{array}$ \\
\hline & 3 & $\begin{array}{c}4.86 \\
(4.84)\end{array}$ & 361 & 375 & 363 & 368 & exo & $-[17.57 \%$ gly $]$ \\
\hline
\end{tabular}

Table 7. Kinetic and thermodynamic parameters of the thermal decomposition of $\left[\mathrm{Cu}(\mathrm{ur})(\mathrm{gly})\left(\mathrm{H}_{2} \mathrm{O}\right)_{2}\right] \mathrm{Cl}$.

\begin{tabular}{|c|c|c|c|c|c|c|c|c|c|}
\hline$\vec{U}$ & 1 & 0.9918 & 3.6 & $3.7 \times 10^{6}$ & 3.2 & 89 & -119.3 & 86.5 & 122.5 \\
\hline 吝 & 2 & 0.9939 & 3.6 & $4.1 \times 10^{7}$ & 334 & 123 & -100.1 & 120.2 & 153.6 \\
\hline ש & 3 & 0.9862 & 4.9 & $1.9 \times 10^{3}$ & 363 & 117 & -183.8 & 114 & 180.7 \\
\hline
\end{tabular}

\subsection{Antibacterial assay of synthesized complexes}

Urea showed activity against the Bacillus spp. and Escherichia coli with inhibitory zones of 12 $\mathrm{mm}$ and $10 \mathrm{~mm}$, respectively and glycine against the Bacillus with inhibitory zone of $9 \mathrm{~mm}$. But no inhibition zone was observed for all the complexes against the four studied strains (Bacillus spp., Escherichia coli, Pseudomonas aeruginosa and Staphylococcus aureus) excepting the complex [Ni(ur) (gly) $\left.\left(\mathrm{H}_{2} \mathrm{O}\right)_{2}\right] \mathrm{Cl}$ which was active against Escherichia coli with inhibitory zone $5 \mathrm{~mm}$. This is probably because urea denatures protein when dissolved, and for the presence of amino and carbonyl groups. However, after complexes formation there would be no activity, due to the coordination of the amino and carbonyl groups ${ }^{31}$.

\section{Conclusions}

The formulae and the stoichiometry of the complexes of urea and glycine with $\mathrm{Co}(\mathrm{II}), \mathrm{Ni}(\mathrm{II})$ and $\mathrm{Cu}(\mathrm{II})$ metal ions are suggested based on the analytical data and TGA results. Neutral bidentate behavior of the urea coordination through the amine nitrogen and carbonyl oxygen is identified by IR spectra. Glycine behaved as an anionic bidentate ligand through the carboxylate group and the neutral amino group. The electrolytic nature of the complexes was confirmed by the molar conductance values. All the complexes have an octahedral geometry, as revealed the spectral and magnetic results. The thermal decomposition studies of $\left[\mathrm{Cu}(\mathrm{ur})(\mathrm{gly})\left(\mathrm{H}_{2} \mathrm{O}\right)_{2}\right] \mathrm{Cl}$ allowed to access the kinetic parameters for the successive steps of its decomposition. The complexes have no 
antibacterial activities against the four strains of bacteria, except the Ni-complex, which is active against Escherichia coli, probably due to protein denaturation.

\section{Acknowledgments}

Authors are grateful to Professor Hussein AlMaydama for his valuable assistance.

\section{References}

[1] Abdel-Rahman, L. H., Abu-Dief, A. M., Ismail, N. M., Ismail, M., Synthesis, characterization, and biological activity of new mixed ligand transition metal complexes of glutamine, glutaric, and glutamic acid with nitrogen-based ligands, Inorganic and Nano-Metal Chemistry 47 (3) (2017) 467-480.

https://doi.org/10.1080/15533174.2015.1137057.

[2] Noyori, R., Chiral metal complexes as discriminating molecular catalysts, Science 8;248 (4960) (1990) 1194-1199. https://doi.org/10.1126/science.248.4960.1194.

[3] Li, Y. T., Yan, C. W., Zhu, Y., Guan, H. S., Synthesis and Magnetic Studies of MOxamidobridged Copper(II)-Manganese(II) Heterobinuclear Complexes, Synth. React. Inorg., Met-Org. Nano-Met. Chem. 34 (2005) 1165-1179. https://doi.org/10.1081/SIM-120039264.

[4] Rahaman ,S. K. H., Fun, H. K., Ghosh, B. K., A Study on Copper(II)-Schiff Base-Azide Coordination Complexes: Synthesis, X-Ray Structure and Luminescence Properties of $\left[\mathrm{Cu}(\mathrm{L})\left(\mathrm{N}_{3}\right)\right] \mathrm{X}(\mathrm{L}=$ Schiff Bases; $\mathrm{X}=\mathrm{ClO} 4, \mathrm{PF} 6)$, Polyhedron 24 (2005) 3091-3097. https://doi.org/10.1016/j.poly.2005.06.028.

[5] Bie, H. Y., Yu, J. H., Xu, Q. J., Li, Y.,. Cui, Y.B., Zhang, Y., Sun, Y. H., Pan, L. Y., Synthesis, Structure and Non-Linear Optical Property of a Copper(II) Thiocyanate Three-Dimensional Supramolecular Compound, Journal of .Molculare Structure $\quad 660 \quad$ (2003) 107-112. https://doi.org/10.1016/j.molstruc.2003.08.011.

[6] Jan, P. A., Harold C., Helgesonb, Solubilities of The Common L-A-Amino Acids as A Function of Temperature Solution $\mathrm{pH}$, Pure and Applied

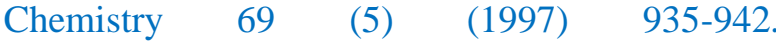
https://doi.org/10.1351/pac199769050935.

[7] Ivanov, A. Y., Sheina, G., Blagoi, Y. P., FTIR Spectroscopic Study of The UV-Induced Rotamerization of Glycine in The Low Temperature Matrices (Kr, Ar, Ne), Spectrochimica Acta Part A (55) (1999) 219-228. https://doi.org/10.1016/S1386-1425(98)00288-1.

[8] Doolittle, R.F., Proteins, Scientific American. 253(4) (1985) 88-91, 94-99. https://doi.org/10.1038/scientificamerican078572.

[9] Kandi, S., Godishala, V., Rao, P., Ramana, K. V., Biomedical Significance of Terpenes: an Insight, Biomedicine and Biotechnology 3 (1) (2015) 8-10. https://doi.org/10.12691/bb-3-1-2.

[10] Kiss, T., Sbvag , I., Gergely, A., Critical Survey of Stability Constants of Complexes of Glycine, Pure and Applied Chemistry 63 (4) (1991) 597-638. https://pubs.sciepub.com/bb/3/1/2.

[11] Jamil, Y. M., Al-Maqtari, M. A., Al-Azab, F. M., Al-Qadasy, M. K., Al-Gaadbi, A. A., Synthesis, Characterization and Comparative Thermal degradation study of $\mathrm{Co}(\mathrm{II}), \mathrm{Ni}(\mathrm{II})$ and $\mathrm{Cu}$ (II) complexes with Asparagine and Urea as mixed ligands, Eclet. Quím. J. 43 (4) (2018) 10-23. https://doi.org/10.26850/1678-4618eqj.v43.4.1124.

[12] Siddiqi, K. S., Kureshy, R. I., Hkan, N. H., Tabassum, S., Zaidi, S. A. A., Characterization and Toxicity of Lanthanide Complexes with Nitrogenand Sulphur-Containing Schiff Bases, Inorganic Chimica Acta 151 (1988) 95-100. https://doi.org/10.1016/S0020-1693(00)91888-7.

[13] El-Metwally, N. M., Gabr, I. M., El-Asmy, A. A., Abou-Hussen, A. A., Spectral, Magnetic, Electrical and Thermal Studies on Malonyl Bis(Thiosemicarbazide) Complexes, Transition Metal Chemistry 31 (1) (2006) 71-78. https://link.springer.com/article/10.1007/s11243005-6347-6.

[14] Amin, R. R., Al-Subaie, A. T., El-Gamal, B. A., Mahasneh, A. M., Al-Naimi, I. S., Chemical, Synthesis, Antimicrobial Activities and Hypoglycemic Effect of Thiosemicarbazide 
Derivatives, Journal of The Medical Research Institute $22 \quad$ (1) (2001) 1-36. https://doi.org/10.13140/RG.2.2.35524.42885.

[15] Nakamoto, K., Infrared Spectra of Inorganic and Coordination Compounds, 2nd Edition, New York, John Wiley Interscience (1970) 166-219. https://doi.org/10.1002/ange.19650771321.

[16] Akmal, S. G., Said, M. T., El-Metwally, N., Synthesis and Spectroscopic Studies of Metal Complexes Formed in The Reaction of Metal Ions with Urea At High Temperature, Journal of The Korean Chemical Society 51 (4) (2007) 339-345. https://doi.org/10.5012/jkcs.2007.51.4.339.

[17] Refat, M. S., Mohamed, G. G., De Farias, R. F., Powell, A. K., El-Garib, M. S., Elkorashy, S. A., M. A. Hussien, M. A., Spectroscopic, Thermal and Kinetic Studies of Coordination Compounds of $\mathrm{Zn}$ (II), Cd (II) and $\mathrm{Hg}$ (II) with Norfloxacin, Journal of Thermal Analysis and Calorimetry 102 (2010) 225-232. https://doi.org/10.1007/s10973-0090404-x.

[18] Refat, M. S., Mohamed, G. G., Ti(IV), Cr(III), $\mathrm{Mn}(\mathrm{II})$, and $\mathrm{Ni}(\mathrm{II})$ Complexes of The Norfloxacin Antibiotic Drug: Spectroscopic and Thermal Characterizations, Journal of Chemical \& Engineering Data 55 (2010) 3239-3246. https://doi.org/10.1021/je100064h.

[19] Omar, B. I., Moamen, S. R., Mahmoud, S., AL-Majthoub, M. M., Chemical Studies on The Uses of Urea Complexes to Synthesize Compounds Having Electrical and Biological Applications, International Journal of Material Science 2 (3) (2012) 67-82. https://docslide.com.br/documents/tiiv-criii-mniiand-niii-complexes-of-the-norfloxacinantibiotic.html.

[20] Anwar, M. H., Chanmiya, S. A. Z., Mahmud, M. A. A., Synthesis and Characterization of Some Metal Complexes of $\mathrm{Zn}$ (II) with 1,10Phenanthroline and Some Amino Acids: AntiInflammatory and Analgesic Activities of Its Complexes, International Journal of Scientific \& Technology Research 2 (9) (2013) 233-237. ISSN 2277-8616. http://www.ijstr.org/finalprint/sep2013/pdf.
[21] Patil, S. S., Shaikh, M. M.., Synthesis, Characterization and Antibacterial Activity of Mixed Ligand Dioxouranium Complexes of 8Hydroxyquinoline and Some Amino Acids, Acta Poloniae Pharmaceutica - Drug Research 69 (4) (2012) 679-686. PMID: 22876610 https://europepmc.org/abstract/med/22876610.

[22] Hosny, W. M., Dioxouranium(VI) Mixed Ligand Complexes Containing 8Hydroxyquinoline and Some Amino Acids, Synth. React. Inorg. Met. Org.Chem. 2 (1998) 1029-1052. https://doi.org/10.1080/00945719809351686.

[23] El-Asmy, A. A., Khalifa, M. E., Rakha, T. H., Hasanian, M. M., Abdallah, A. M., Mono and trinuclear complexes of oximinoacetoacetylpyridine-4-phenylthiosemicarbazone, Chem. Pharm. Bull. 48 (2000) 41-44. https://doi.org/10.1248/cpb.48.41.

[24] Saha, N. C., Butcer, R. J., Chaudhuri, S., Saha, N., Synthesis and spectroscopic characterisation of cobalt (III) and nickel (II) complexes with 5methyl-3-formylpyrazole-N dibutylthiosemicarbazone (HMP z NBu 2): X-ray crystallography of $\left[\mathrm{Co}\left(\mathrm{MPz} \mathrm{NBu}_{2}\right)_{2}\right] \mathrm{NO}^{3 \cdot} \mathrm{H}_{2} \mathrm{O}$ (I) and $\left[\mathrm{Ni}(\mathrm{HMPz} \mathrm{NBu})_{2}\right]\left(\mathrm{ClO}_{4}\right)_{2}$ (II), Polyhedron 22 (3) 383-390. https://elibrary.ru/item.asp?id=1350301.

[25] El-Asmy, A. A., Mounir, M., Electrical conductivity, spectral and magnetic properties of some transition metal complexes derived from dimedone bis(4-phenylthiosemicarbazone), Transition Metal Chemistry 13 (2) (1988) 143-145. https://link.springer.com/article/10.1007/BF01087 807.

[26] Amin, R. R., Elgemeie, G. E. H., The Direct Electrochemical Synthesis of Co(II), Ni(II) and $\mathrm{Cu}$ (II) Complexes of Some Pyridinehtione Derivatives, Synthesis and Reactivity in Inorganic and Metal-Organic Chemistry 31 (3) (2001) 431440. https://doi.org/10.1081/SIM-100002230.

[27] El-Metwally, N. M., El-Asmy, A., Chelating Activity

Bis(Diacetylmonoxime)Thiocarbohydrazone

Towards $\mathrm{VO}^{2+}, \mathrm{Co}(\mathrm{II}), \mathrm{Ni}(\mathrm{II}), \mathrm{Cu}(\mathrm{II})$ and $\mathrm{Pt}(\mathrm{IV})$ Ions, Journal of Coordination Chemistry 59 (14) (2006)

1591-1601.

https://doi.org/10.1080/00958970600572743. 
[28] El-Asmy, A. A., Khalifa, M. E., Hassanian, M. M., Synthesis and Characterization of Transition Metal Complexes Containing Oxime, Amido and Thioamido Groups, Indian Journal of Chemistry 43 (A) 92-97. https://doi.org/10.1080/00958970600572743.

[29] El-Asmy, A. A., Al-Ansi, T. Y., Amin, R. R., Mounir, M. M., Spectral, Magnetic and Electrical Properties of 1-Succinyl Bis (4Phenylthiosemicarbazide) Complexes, Polyhedron $9 \quad$ (17) (1990) 2029-2034. https://doi.org/10.1016/S0277-5387(00)84032-2.

[30] El-Shekeil, A., Almaydamah, H., AlKarbooly, A., Poly[4-Amino-2,6Pyrimidinodithiocarbamate] and Its Cobalt, Nickel, and Copper Complexes, Journal of Inorganic and Organometallic Polymers and Materials $\quad 7 \quad$ (1997) 121-133. https://doi.org/10.1023/A:1021444328744.

[31] Abdel-Rahman, L. H., Abu-Dief, A. M., Ismail, N. M., Ismael, M., Synthesis, characterization, and biological activity of new mixed ligand transition metal complexes of glutamine, glutaric, and glutamic acid with nitrogen-based ligands, Inorganic and Nano-Metal Chemistry $47 \quad$ (3) (2017) 467-480. https://doi.org/10.1080/15533174.2015.1137057. 